\title{
Michelle Szkilnik, The Art of Compiling in Jean de Bueil's 'Jouvencel' (1461-1468)
}

\section{Paola Cifarelli}

\section{(2) OpenEdition}

1 Journals

\section{Édition électronique}

URL : https://journals.openedition.org/studifrancesi/3029

DOI : 10.4000/studifrancesi.3029

ISSN : 2421-5856

\section{Éditeur}

Rosenberg \& Sellier

\section{Édition imprimée}

Date de publication : 1 juillet 2013

Pagination : 437

ISSN : 0039-2944

\section{Référence électronique}

Paola Cifarelli, « Michelle Szkilnik, The Art of Compiling in Jean de Bueil's 'Jouvencel' (1467-1468) », Studi Francesi [En ligne], 170 (LVII | II) | 2013, mis en ligne le 30 novembre 2015, consulté le 02 février 2023. URL : http://journals.openedition.org/studifrancesi/3029; DOI : https://doi.org/10.4000/studifrancesi. 3029

Ce document a été généré automatiquement le 2 février 2023.

\section{(c) (†) $\ominus$}

Creative Commons - Attribution - Pas d'Utilisation Commerciale - Pas de Modification 4.0 International - CC BY-NC-ND 4.0

https://creativecommons.org/licenses/by-nc-nd/4.0/ 


\title{
Michelle Szkilnik, The Art of Compiling in Jean de Bueil's 'Jouvencel' (1461-1468)
}

\author{
Paola Cifarelli
}

\section{RÉFÉRENCE}

MICHELLE SZKILNIK, The Art of Compiling in Jean de Bueil's 'Jouvencel' (1461-1468), «Fifteenth Century Studies», 36, 2011, pp. 169-179.

1 Le roman de Jean de Bueil est utilisé ici comme point de départ pour une réflexion plus vaste sur l'art de la compilation, qui implique une comparaison avec le Livre des faits d'armes et de chevalerie de Christine de Pizan, dans le but de montrer que les procédés d'appropriation du texte de Végèce chez les deux auteurs sont complexes tant dans la technique adoptée que dans les visées qu'ils poursuivent; celles-ci sont identifiées avec la volonté de perfectionner et rendre plus précise la description des tactiques militaires. Le matériau antique sert également à accroître le prestige du nouveau texte en contribuant à l'élever au rang d'autorité. 